\title{
Cleavage Agama Di Tingkat Lokal, Indonesia: Identifikasi Partai Tanpa
}

\section{Komitmen Electoral}

\author{
Asep Nurjaman* \\ asepip@umm.ac.id
}

\begin{abstract}
Abstrak
Performa partai-partai Islam di Indonesia pada setiap pemilihan umum senantiasa stabil meskipun mengalami penurunan jumlah suara. Dalam tulisan ini, kami berupaya menginvestigasi sosialisasi politik kelompok religius (NU) dalam partai Islam (PKB).Telah diketahui secara luas bahwa santri (Muslim taat menurut Geertz) baik yang tradisional maupun yang modern sedang mengalami penurunan dalam demokrasi di Indonesia. Penelitian ini bertujuan untuk menganalisis faktor-faktor yang menyebabkan melemahnya hubungan antara kelompok agama dan partai. Metode yang digunakan adalah metode kualitatif. Pengumpulan data dilakukan melalui teknik observasi, wawancara dan Focus Group Discussion. Hasil studi ditujukan bahwa NU dan Muhammadiyah tidak mendukung lagi PKB dan PAN. Sejak kelompok Islam bentuk bebas politik kesejajaran, Santri pemilih yang sekarang, lebih pragmatis dan cairan dalam pemilihan. Hasil dari penelitian ini menunjukkan bahwa NU dan Muhammadiyah tidak lagi mendukung PKB dan PAN. Sejak kelompok Islam mendapat kebebasan dalam berpolitik, santri pemilih lebih pragmatis dan fleksibel dalam menentukan pilihannya pada pemilihan umum.
\end{abstract}

Kata kunci: Kelompok agama, Muhammadiyah, NU, partai politik, pemilu.

\begin{abstract}
The Performance of Islamic parties in Indonesia form one election to the next, despite are going to decrees but still exist. In this paper we investigate the political sosialization of religious Group (NU) on Islamic Parties (PKB). It is widely recognized that Santri (devout Muslim as categorized Geertz) both traditional and modernism is declining in Indonesian democracies. This study aims to analyze the factors caused the weakening of the relation between religious group and the party. The method used is a qualitative research. Technique data collection likes observation, interview and Focus Group Discussion are used. The results of the study addressed that NU and Muhammadiyah do not Support any more to PKB and PAN. Since Islamic group free form political alignment, Santri voters are now, more pragmatic and liquid in the election.
\end{abstract}

Key Words: Election, Mubammadiyah, NU, Political Parties, Religious Group

\section{Pendahuluan}

Menurut Rose and Urwin (1969) hasil kajian di 17 negara demokrasi justru agama, bukan kelas, yang paling banyak menjadi pendukung partai. Hal ini diperkuat oleh kajian Lijphart (1979) yang mempertimbangkan kekuatan relative kelas, agama, dan bahasa dalam menentukan pemilih di empat Negara yang keempat cleavages tersebut

*Korespondensi: Prodi Ilmu Pemerintahan. Fakultas Ilmu Sosial dan Ilmu Politik. GKB I Lt.6. Universitas Muhammadiyah Malang, Jl. Raya Tlogomas no. 246 Malang, telp. 0341 464318, Email: asepip@umm.ac.id 
berkembang saat seperti Belgia, Kanada, New Zeland, dan Afrika Selatan,. Agama unggul dalam tiga Negara; bahasa unggul di satu Negara yaitu Afrika Selatan. Hasil kesimpulan dari Lijphart (1982) menunujukan penilaian yang kompromistis: Kelas sosial sangat penting khususnya di negara-negara demokrasi industri dan agama seringnya tidak begitu penting. Namun ketika kelas sosial dan agama ini memainkan peranan, maka ada kecenderungan agama punya pengaruh kuat pada pilihan partai (Harrop \& Miller, 177178).

Berlandaskan pada pandangan tersebut di atas, sesuai dengan arah penelitian yang saya lakukan, mengkaji proses sosialisasi yang terjadi didalam kelompok agama menjadi signifikan. Kajian proses sosialisasi akan di fokuskan pada kelompok Islam Santri baik yang tradisional (NU) maupun modernis (Muhammadiyah), namun penekanan lebih dalam akan terfokus pada proses sosialisasi yang terjadi dalam kelompok Santri Trdisional. Dalam masyarakat Nadliyin, proses sosialisasi terjadi baik dalam keluarga maupun kelompok secara instens. Perbedaan perilaku keberagamaan secara umum, antara Santri Tradisional dan Santri Modernis terletak pada aspek ritual keagamaan seperti tahlilan, Yasinan, Dibaan, Istighosahan, Slametan, Kunjungan ke makam para wali, yang hal ini menjadi ciri khas dari kelompok Santri Tradisional.

Proses sosialisasi merupakan kajian penting dalam pendekatan psikologi. Salah satu hasil kajian yang paling signifikan dalam keterlibatan seseorang dalam politik adalah pentingnya atau kuatnya faktor keluarga dalam menentukan sikap atau perilaku. Ketika orang tua punya keyakinan akan norma serta tata nilai tertentu tentang politik, maka keyakinan politik tersebut akan ditransmisikan kepada anak-anak mereka (Harrop \& Miller, 177-178). Disamping keluarga agen yang juga sangat penting dalam sosialisasi adalah kelompok, berbagai pandangan, pemikiran, sikap yang disampaikan baik melalui lisan maupun tulisan atau dalam bentuk komunikasi lain. Ketika kelompoknya punya program politik, anggota yang mengidentifikasikan dirinya dengan kelompok tersebut akan juga mengidentifikasikan program tersebut sebagai programnya juga (Lane, 1959: 189).

Santri maupun Abangan, yang menjadi pondasi dasar bekerjanya politik 
aliran. Identifikasi politik pemilih merupakan produk dari proses sosialisasi panjang yang terjadi di arena keluarga, masyarakat, dan lingkungan kerja. Dengan demikian identifikasi diri seseorang terhadap kelompok, organisasi, atau partai bukan terjadi secara tiba-tiba. Proses identifikasi terjadi secara kontinyu dan membutuhkan waktu yang panjang lewat sosialisasi yang terus menerus. Seberapa besar tingkat identifikasi seseorang terhadap kelompok, organisasi, atau partai sangat bergantung kepada berapa lama seseorang terlibat atau berada di dalamnya, serta berapa intens komunikasi yang terjalin. Oleh karena itu bagi mereka yang sudah tua, karena sudah lama mengalami proses sosialisasi, maka tingkat identifikasi dirinya akan kuat dibanding dengan mereka yang masih muda.

Dengan demikian, orang-orang muda akan relatif lebih mudah keluar atau pindah dan bergabung dengan kelompok, organisasi, atau partai baru ketimbang orang yang sudah tua. Proses sosialisasi yang terjadi dalam masyarakat baik itu yang terjadi dalam kelompok Abangan maupun Santri, sudah terjadi sejak dini. Dala kelompok Abangan proses sosialisasi dilakukan lewat berbagai kegiatan kesenian seperti Jaranan, Bantengan. Sementara proses sosialisasi dalam kelompok Santri, khususnya santri Tradisional dilakukan lewat berbagai aktifitas keagamaan. Hasil observasi di wilayah Malang Raya selama penelitian ini dilaksanakan. Hasil studi Bibby juga menunjukan bahwa orang-orang muda menunjukan kecenderungan rendah partisipasinya dalam pemilu, hanya sekitas 18,6 - 20 persen saja mereka yang berusia 18 tahunan berpartisipasi dalam pemilu (Bibby, 1992: 259).

\section{Relasi Agama dan Politik}

Terseretnya agama dalam politik bukanlah hal yang aneh, karena secara riil pemeluk agama, khususnya pemeluk Islam, di Malang Raya merupakan pemeluk agama yang umumnya terkategorikan Tradisional dengan tingkat kepanatikan terhadap agama yang tinggi. Dari segi kuantitas, sebagai contoh, jumlah pemeluk agama Islam di Malang Raya merupakan mayoritas, dibanding dengan agama lain seperti Kristen kira-kira hanya 5\%, Katolik sekitar 4\% dan Hindu dan Budha merupakan minoritas ketiga dan keempat.

Memahami tingginya korelasi agama dan partai politik, Komaruddin Hidayat 
dan M. Yudhi Haryono (2004), menyebutkan bahwa fenomena partai dan politik agama bisa dijelaskan dengan tiga cara: Pertama, agama adalah politik, atau lebih tepatnya produk politik. Berbagai fakta sejarah menunjukan bahwa kelahiran agama (terutama agama Ibrahimian) adalah kritik perlawanan, pemberontakan, dan pembebasan dari hegemoni dan sistem politik rezim penguasa. Agama menjadi kumpulan daya kohesif yang mengikat umat untuk melakukan perlawanan.

Kedua, agama adalah stuktur penyelamat yang menghasilkan agen penyelamatan. Agama berkaitan dengan usaha-usaha manusia untuk mengukur dalamnya makna dan keselamatan sendiri, kelurga dan keselamatan alam semesta. Karenanya agama juga telah menimbulkan khayalan yang paling luas dan digunakan untuk membenarkan kekejaman pada orang lain, membangkitkan kebahagiaan, dan menjalari rasa takut yang luar biasa, sehingga gagasan penyelamatan demikian sentral dalam setiap agama.

Ketiga, agama adalah alat analisis sekaligus jawaban persoalan dunia. Ia adalah sumber pembaharu-pembaharu yang kreatif. Karena paradigma inilah, kita bisa melihat jejak rekam para nabi yang ditempatkan sebagai tempat bertanya sekaligus tempat menjelaskan problem umat (Hidayat \& Haryono, 2004).

Walaupun demikian, dalam kalangan Islam sendiri tidak homogen. Banyak aliran pemikirian yang berkembang, dan pada akhirnya menjadi mainstrem baru dalam mazhab pemikiran Islam. Perbedaan pemikiran ini tidak hanya dalam hal kehidupan sosial, namun juga dilatar belakangi persoalan politik. Berkembangnya perbedaan pandangan politik di dalam Islam bersumber pada perbedaan pemikiran tentang relasi Islam dan Negara. Secara epistemologis maupun ontologis ada perbedaan mendasar mengenai konsep demokrasi antara Barat dan Islam. Demokrasi Barat kosep dasarnya adalah kedaulatan rakyat, sementara dalam Islam adalah kedaulatan Tuhan.Dalam khazanah pemikiran umat Islam, diskursus tentang Islam dan Negara memang bukan barang baru. Diskursus ini telah berlangsung sangat lama, namun sampai sekarang belum juga berakhir. Ini menandakan bahwa masalah Islam dan negara merupakan masalah laten yang akan terus mewarnai diskursus politik nasional. 
Kalau kita menengok ke belakang, sejarah berdirinya partai politik Islam di inspirasi oleh adanya keinginan untuk membentuk wadah politik tunggal untuk perjuangan ummat Islam pasca kemerdekaan 1945. Sesuai dengan manifestasi politik pemerintah yang ditandatangani oleh Wakil Presiden Mohammad Hatta bulan November 1945 semua golongan ummat Islam sepakat untuk membentuk suatu wadah politik tunggal yang bernama MASYUMI.

Partai Politik Masyumi ini didukungan oleh organisasi-organisasi Islam besar seperti NU, Muhammadiyah, dan PSII. Akan tetapi kebersamaan ketiga ormas Islam ini mengalami perpecahan dalam mendukung Masyumi pada tahun 1948 dengan dibentuknya kembali Partai Syarikat Islam Indonesia (PSII) dibawah pimpinan Arudji Kartawinata, Abikoesno Tjokrosoejoso dan lain-lain. Kemudian pada tahun 1953 disusul dengan keluarnya Nahdlatul Ulama (NU) dan menjadi partai politik sendiri. Dan akhirnya, sebagai benteng terakhir, Muhammadiyah menyatakan diri untuk tidak lagi menjadi anggota istimewa dari Masyumi sebelum partai ini dibubarkan pada tahun 1960 (Mintaredja, 1971).

Pada masa Orde Baru partai Islam mengalami kehancuran akibat adanya fusi partai politik yang hanya membolehkan dua partai yaitu partai berhaluan agama yang diwakili PPP dan partai yang berhaluan Nasionalis yang diwakili PDI (Mohtar Mas'oed, 1994). Pada masa ini partai Islam banyak ditinggalkan konstituennya akibat adanya tekanan dan politik adopsi dari penguasa sehingga pemilih Islam banyak yang lari ke Golkar sebagai partai pemerintah. Ketika rezim Orde Baru berakhir, Partai Islam kembali berkembang. Pada pemilu 1999 tercatat ada sekitar 114 partai yang secara tegas mencantumkan Islam sebagai asas maupun yang secara sosiologis termasuk partai Islam yaitu PAN dan PKB yang berasas Pancasila. Sementara pada pemilu 2004, Partai Islam tidak sebanyak pada pemilu 1999.

\section{Dukungan Kelompok Keagamaan}

Sebelum membahas lebih jauh terkait dukungan ormas keagamaan pada partai politik, perlu kiranya dikemukakan bagaimana relasi partai dan agama sebagai 
justifikasi masuknya agama dalam ranah politik.Angus Campbell (1976) menunjukan adanya korelasi antara variable agama dalam pemungutan suara disamping variable ras, pekerjaan, pendidikan, dan pendapatan.

Pada pemilu 1999 dan 2004, di Malang Raya walaupun secara tidak langsung menjadikan ormas Islam sebagai partai politik, namun pada praktiknya agama dijadikan sebagai alat untuk memobilisasi massa. Ada alasan yang kuat kenapa banyak partai politik menggunakan organisasi massa atau agama sebagai dasar atau basis dalam partai politik. Salah satu alasannya adalah tidak berkembangnya basis sosial secara material, seperti yang diperlihatkan oleh lemahnya pengelompokan profesi yang akan memobilisasasi massa untuk mendukung partai politik. Di Indonesia, khususnya di Malang Raya, justru alat mobilisasi massa yang paling efektif adalah agama, dalam hal ini Islam. Pemeluk agama Islam tidaklah homogen karena ada varian-varian yang bisa dilihat dari karakteristik penganutnya. Salah satu pencetus dari varian Islam itu adalah Geertz, yang mengemukakan bahwa pemeluk agama Islam terkategorisasikan kedalam tiga, yaitu Santri, priyayi dan Abangan.

Setidaknya ada dua karya terpenting sering jadi rujukan jika membicarakan masyarakat Islam dalam konteks Indonesia. Pertama, The Religion of Java karya Clifford Geertz yang didasarkan studi di Mojokuto, sebuah desa kecil di Jawa Tengah. Kedua, Indonesia Political Thinking karya Herbert Feith dan Lance Castles yang mengacu pada koleksi tulisan sejumlah tokoh Indonesia. Kedua karya tersebut ditulis sekitar tahun 1950-1960-an. Hasil studi Geertz intinya mengungkapkan temuan trikotomi politik aliran. yaitu: Abangan, Santri, dan priyayi. Abangan adalah ciri kelompok masyarakat yang berbasis pertanian (pedalaman) dengan orientasi keagamaan tidak ketat. Santri adalah berbasis pada perdagangan (perkotaan) dengan orientasi keagamaan yang kuat. Sedang priyayi yang berbasiskan birokrasi berorientasi lebih kental pada warisan tradisi aristokrat atau pamong. Berbeda dengan teori Gertz, formulasi Feith mengungkap lima kutub aliran. Yaitu, Islam, Nasionalisme radikal, sosialisme, komunisme, dan Tradisionalisme Jawa. Tumbuhnya kelima aliran itu dipengaruhi oleh dua sumber utama, yakni: khasanah Barat (modern) dan domestik (Hindu-Buddha dan Islam). Dari situlah 
mengejawantah heterogenitas partai.

\section{Dukungan Politik Muhammadiyah Dan NU}

Di Indonesia dan kuhususnya di Malang Raya ada dua kekuatan poros besar Ormas Islam. Sebenarnya masih ada Ormas Islam selain Muhamamdiyah dan NU, tapi tidak sebesar pengaruhnya terhadap kehidupan masyarakat Indonesia jika dibandingkan dengan kedua Ormas Islam tersebut. Pada perjalanannya Ormas Islam ini juga tidak pernah lepas dari kegiatan politik Indonesia. Walaupun dalam AD/ART Ormas Islam itu tidak secara frontal menyebutkan Ormas ini terjun di dunia politik. Tetapi tidak dapat dipungkiri bahwa baik secara langsung maupun tidak langsung Ormas Islam yang ada tidak dapat dikatakan bebas dari keterlibartan dalam dunia politik. Bisa di amati dalam perjalanan peta panggung politik di Indonesia, nama Muhammadiyah berada di belakang pendirian Partai Amanat Nasional. Demikian juga NU dengan nahdliyinnya berada di belakang Partai Kebangkitan Bangsa. Bahkan setelah muncul nama PKB ada juga PKNU yang juga mengklaim dirinya sebagai partai warga Nahdliyin (sebutan untuk warga Nahdlotul Ulama) selain Partai Kebangkitan Bangsa yang telah lebih dahulu terbentuk.

Pertama kali NU terjun ke politik secara langsung yaitu pada saat NU menyatakan keluar dari Masyumi tahun 1952, kemudian mendirikan partai politik sendiri dan ikut dalam pemilu 1955. Perolehan sura NU cukup signifikan karena meraih 45 kursi di DPR dan dan menjadi empat besar perolehan suara.

Semenjak memenangkan perolehan suara empat besar dalam pemilu 1955 , kiprah NU dalam politik tidak begitu besar. Ketika Orde Baru yang menempatkan NU dalam satu kantung dengan PPP, banyak kader NU yang tidak menjadi wakil di parlemen. Hal ini telah menyebabkan banyak tokoh NU yang kecewa sehingga lahir satu gagasan untuk keluar dari penyangga utama suara PPP. Akhirnya pada muktamar NU di Situbondo, NU menyatakan diri untuk kembali ke khitah 1926 yaitu tidak aktif dalam politik praktis.

Secara formal, kembali ke khitah 1926, sampai terjadinya reformasi politik 
tidak berubah. Akan tetapi para elit NU, khususnya Gusdur membentuk PKB sebagai wadah dari aspirasi warga NU. Karena Gusdur merupakan cucu dari pendiri NU yaitu Kh. Hasyim Asari, maka banyak kyai yang menjadi pendukung PKB. Dengan demikian bisa dikatakan bahwa dukungan NU pada PKB bukanlah dukungan formal organisasi, melainkan dukungan informal karena di PKB ada Gusdur yang merupakan tokoh NU.

Begitupun Muhammadiyah, setelah tidak mendukung Masyumi dan keluar dari Parmusi, hubungannya dengan partai politik secara organisatoris sudah tidak ada lagi. Walau demikian, banyak dari kader-kader Muhammadiyah yang aktif di politik baik itu di Golkar, PPP, bahkan PDI (masa Orde Baru). Keberadaan mereka di partai politik tidak mewakili secara organisasi, tapi mewakili keberadaan mereka secara pribadi. Karena perjalanan politik Parmusi tidak baik karena banyak terjadi konflik dan perebutan kekuasaan, maka Muhammadiyah memutuskan untuk keluar dari Parmusi. Dan sampai sekarang Muhammadiyah tidak pernah ikut dalam kehidupan politik praktis. Kelahiran Parmusi merupakan hasil dari khitah 1969 di Ponorogo. Dalam rumusan khitah tahun 1969 disebutkan bahwa dakwah Islam amar ma'ruf nahi mungkar dilakukan melalui dua saluran: politik kenegaraan dan kemasyarakatan. Dan dengan khitah ini menjadi legitimasi Muhammadiyah untuk terjun ke politik dengan ikut mendukung kelahiran Parmusi.

Seperti halnya NU, ketika salah satu tokoh Muhammadiya yaitu Amin Rais mendirikan PAN, maka banyak dari kader Muhammadiyah yag ikut terjun dalam kepengurusan PAN baik di pusat maupun di daerah. Bahkan di Malang Raya terbentuknya kepengurusan PAN, hampir semuanya dimotori oleh kader-kader Muhammadiyah. Walaupun demikian, tidak semua warga Muhammadiyah setuju dan ikut PAN, karena banyak warga Muhammadiyah yang menyangsikan dalam hal ideologi karena PAN tidak mencantumkan Islam sebagai asas partai. Pada pemilu 2004 dan 2009 karena menganggap PAN tidak jelas ideologinya, maka banyak warga Muhammadiya yang mengalihkan pilihan politiknya ke PKS yang dianggap lebih islami. Disamping itu animo yang berkembang dikalangan warga Muhammadiyah sendiri, bahwa warga Muhammadiyah yang terlibat di PAN itu lebih banyak mewakili perorangan. Mereka yang 
duduk di legislatif yang diharapkan mampu membawa aspirasi Muhammadiyah ternyata tidak begitu memberikan banyak pengaruh terhadap perkembangan Muhammadiyah. Lebih jauh, warga Muhammadiyah, khususnya perorangan yang ada di Legislatif dalam perjalanannya mereka menjadi wakil rakyat terkesan tidak punya citra positif di kalangan warga Muhammadiyah.

\section{Kyai: Patron Sosial Dan Politik}

Dalam masyarakat Desa Jawa, tipe kepemimpinan dimiliki baik oleh pemimpin yang mempunyai posisi dalam birokrasi formal sebagai kepala desa, dan pemimpin diluar birokrasi, khususnya pemimpin spiritual. Dalam kasus ini, Sartono Kartodidjo berpendapat bahwa, "diluar pejabat pemerintahan terdapat juga pemimpin alami yang berkuasa seperti kyai lokal, haji, guru, dukun” (Sartono Kartodirdjo 1972). Para pemimpin tersebut mempunyai atribut tertentu seperti jimat yang memberikan perlindungan dari bahaya, mempunyai ilmu kedigjayaan, ilmu pengetahuan, ilmu keselamatan, yang memberi kekuasaan sebagai manusia lebih. Tipe kepemimpinan ini dapat membentuk perilaku politik dalam negara berkembang seperti Indonesia.

Masyarakat Malang Raya dikenal dengan masyarakat yang berbasis NU, namun hal itu lebih merupakan corak dari kehidupan masyarakat yang Islami, seperti menjadikan kyai atau ulama-ulama sebagai Patron yang dihormati sekaligus menjadi panutan dalam kehidupan spiritualnya. Anderson menyebutkan bahwa dalam komunitas Islam, orang yang mempunyai status tertinggi adalah mereka yang berpengetahuan tinggi mengenai hukum agama dan mereka yang mengajarkan ajaran Islam (Anderson, 1990: 61). Kondisi ini secara tidak langsung diwariskan turun temurun, dari generasi ke generasi mengikuti kebiasaan menjadikan kyai ataupun ulama-ulama tertentu sebagai panutan.

Lebih jauh, walaupun masyarakat Malang Raya secara kultural berbeda dengan kultur masyarakat Jawa Timur pada umumnya, khususnya wilayah kultur padalungan, namun pola budaya paternalis yang memberikan stratifikasi tertinggi pada kyai berkembang. Menurut Prawiroatmojo (1985), kata pandalungan berasal dari kata 
dasar "dhalung" artinya periuk besar. Wadah bertemunya budaya sawah dengan budaya tegal atau budaya Jawa dengan budaya Madura, yang membentuk budaya Pandalungan. Hasilnya, masyarakat yang berciri agraris-egaliter, bekerja keras, agresif, ekspansif, dan memiliki solidaritas yang tinggi, tetapi masih menempatkan pemimpin agama Islam sebagai tokoh sentral. Daerahnya meliputi Pasuruan, Probolinggo, Situbondo, Bondowoso, Lumajang, dan Jember (Prawiroatmojo, 1985).

Kondisi sosial demikian berimplikasi pada pola hubungan sosial dan pola komunikasi yang terjadi dalam masyarakat. Kyai menjadi sosok panutan dan tauladan dalam setiap gerak dan langkahnya. Oleh karena itu apa yang menjadi ucapan dan tindakan kyai menjadi contoh dan pegangan masyarakat, tidak hanya dalam urusan sosial, namun juga masuk ke dalam ranah politik. Fenomena kepatuhan kepada kyai bukan hanya fenomena lokal, akan tetapi boleh dikatakan pola umum yang terjadi di masyarakat Jawa, dan Indonesia pada umumnya. Sebagai contoh hasil penelitiannya Karl D. Jackson (1973) di Jawa Barat mengenai kewibawaan Tradisional.

Peran sentral kyai di dalam masyarakat telah membuat kyai menjadi orang yang ditaati dan dipatuhi oleh masyarakat tidak hanya dalam kehidupan sehari-hari secara sosial, namun juga secara politik. Di Malang Raya ada banyak pesantren baik yang berskala besar maupun kecil, dan lingkungan masyarakatnya sangat kental dengan suasana keagamaan Santri, khususnya Santri Tradisionalis. Oleh karena itu tidaklah salah apabila kehidupan sosial masyarakat di Malang Raya sangat dipengaruhi oleh peran ulama atau kyai.

Pada saat pemilu, seorang kyai lokal di Malang Raya sangat besar pengaruhnya dalam menentukan arah kemana masyarakat akan memilih partai politik, dan kondisi ini telah melahirkan pemilih-pemilih yang loyal. Semakin dekat dengan kultur pesantren atau dengan dengan lingkungan kyai, maka semakin besar pengaruh kyai tersebut pada pilihan politik masyarakat. Kecenderungan umum pemilu pemilu 1999 dan 2004, para kyai lokal di Malang Raya mengidentifikasikan dirinya dengan partai Islam, khususnya PKB, walaupun ada sebagian kecil yang menyebrang ke PPP, PPNU atau ke partai Islam lainnya. Para kyai lokal yang ada di Malang Raya umumnya punya ikatan 
sosiologis dengan PKB, karena umumnya mereka pernah ngaji di pondok Tebu Ireng yang didirikan oleh KH. H. Hasyim Asari yang merupakan pendiri dari Nahdatul Ulama. Sementara salah seorang cucu pendiri NU, Abdurahman Wahid, merupakan pendiri dari PKB. Oleh karena itu sebagai seorang Santri Tradisional yang sangat menghormati guru dan keturunannya, maka banyak kyai di Malang Raya mendukung PKB karena ada figur Gus Dur. Sementara bagi kyai yang tidak mendukung PKB umumnya karena ada unsur kedekatan pribadi dengan tokoh atau elit politik yang duduk dalam kepengurusan partai tersebut.

Oleh karena itu, lingkungan yang ada pesantren maka ada kecenderungan kuat di wilayah tersebut PKB menang, sementara masyarakat santri tradisional yang jauh dari pusat pesantren ada kecenderungan pilihan politiknya menyebar. Hasil analisis dokumen pemilu menunjukan bahwa untuk wilayah-wilayah yang ada pesantren, PKB mendapatkan suara cukup signifikan juka dibanding dengan wilayah-wilayah yang tidak ada pesantren. Menurut data yang ada, khusus untuk wilayah Kabupaten Malang dan Kota Malang, jumlah pesantren yang terdaftar berjumlah 48 pesantren. (www.pesantrenvirtual.com)

Gambar 5.1. Model Pola Pembentukan Loyalitas pemilih Santri Tradisional

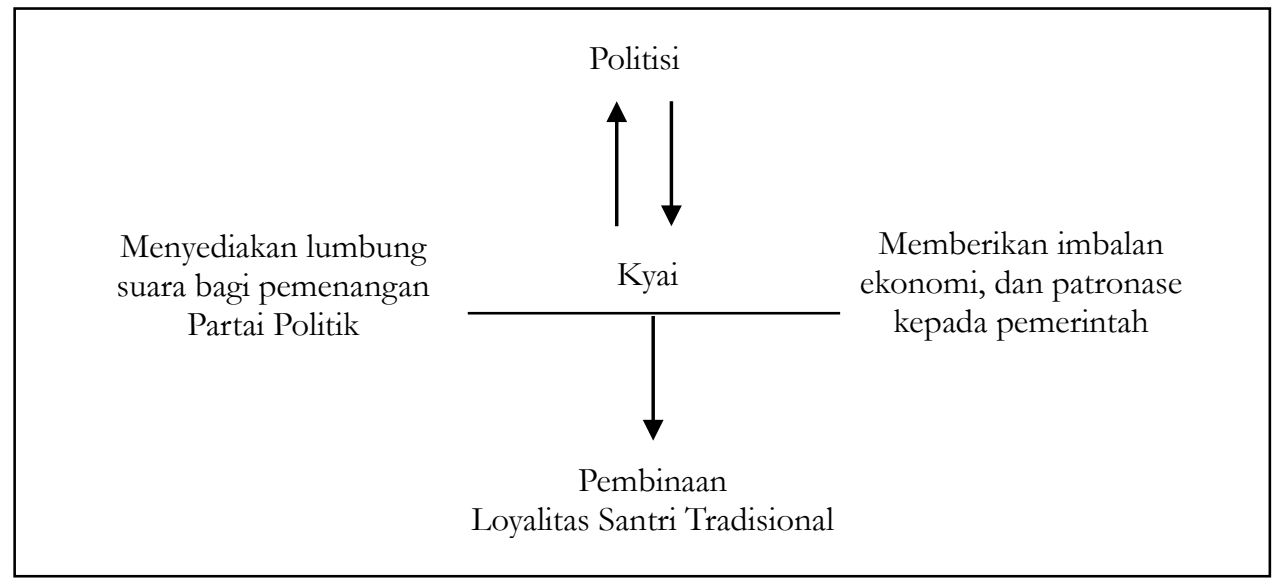

Karena pilihan politik kaum Santri Tradisionalis itu tidak independen (ketergantungan pada kyai), maka ada kecenderungan pilihan politiknya seragam. Namun 
di sisi lain keputusan politik kyai sangat independen, karena sangat bergantung pada keterikan spikologis maupun ekonomis. Oleh karena itu para kyai lokal, atas dorongan kepentingannya baik itu pembangunan, maupun eksistensi diri, maka ada yang melakukan pengalihan politik dari alur kebanyakan. Hasil observasi penulis di wilayah Singosari Kabupaten Malang, Lowok Waru Kota Malang, dan Caru Kota Batu.Di Malang Raya umumnya, para kyai lokal menyalurkan aspirasi politiknya ke PKB karena dalam PKB ada Gus Dur. Namun demikian ada sebagian ulama atau kyai yang tidak mendukung PKB, tetapi mendukung partai Islam lain seperti PPP, PPNU (PKNU 2009) atas dasar kepentingan dan kedekatan pribadi dengan pimpinan partai tersebut.

Tabel 5.1. Perolehan Suara PKB Pada Pemilu 1999 dan 2004 di Malang Raya

\begin{tabular}{l|c|c|c|c|}
\multirow{2}{*}{\multicolumn{1}{c|}{ Nama Wilayah }} & \multicolumn{2}{|c|}{ Perolehan Suara } & \multicolumn{2}{c|}{ Prosentase } \\
\cline { 2 - 5 } & 1999 & 2004 & 1999 & 2004 \\
\hline Kabupaten Malang & 392.472 & 316.665 & $29,57 \%$ & $25,72 \%$ \\
\hline Kota Batu & & 14.148 & & $13,19 \%$ \\
\hline Kota Malang & 77.429 & 68.321 & $19,60 \%$ & $17,36 \%$
\end{tabular}

Sumber: KPUD Kabupaten dan Kota Malang, Kota Batu yang telah diolah penulis.

Keterangan: Pada pemilu 1999, status Kota Batu masih Kota Administratif di bawah Pemerintahan Kabupaten Malang.

Hasil wawancara dengan Muslimin pada bulan Februari 2008 di Caru Pendem Kota Batu menggambarkan peran kyai lokal terhadap kemenangan PKB sangat strategis. Secara tersirat kyai memberikan informasi, isu dan gagasan politik melalui berbagai aktivitas keagamaan dari mulai pengajian, tahlilan, istighosah dan lain sebagainya. Kegiatan ini menjadi penting dalam mendulang suara, karena pesan yang tersirat adalah "apabila mengaku warga nahdilyin, maka PKB harus menjadi pilihan politiknya". Dengan demikian, banyak dari warga Nahdilyin yang sangat fanatik dengan pilihan politiknya. Mereka tidak merasa nyaman dan aman secara sosial apabila memilih partai politik selain partai yang dilahirkan oleh NU ini. Sikap yang tidak mau berbeda dengan lingkungan sangat kental dalam lingkungan masyarakat Santri Tradisional maupun abangan, khususnya masyarakat yang tinggal di pendesaan. Pilihan politik santri 
tradisional ke PKB yang cukup, tidak lain karena mereka takut dianggap bukan bagian dari kelompok mereka. Hasil perolehan suara PKB di Malang Raya pada Pemilu 1999 dan 2004 bisa dilihat dalam tabel 5.1.

Keberpihakan massa Santri Tradisional kepada partai Islam, khsusnya PKB, yang merupakan dampak dari adanya peran kyai, bisa dijelaskan dalam perspektif budaya masyarakat Jawa. Budaya patron-clien atau hubungan "bapakisme" yang berkembang, menjadikan pilihan politik kyai menjadi pijakan masyarakat untuk menentukan pilihan politiknya. Hubungan sosial "bapakisme" lebih halus dari pada hubungan patron-client yang banyak terdapat di beberapa Negara Asia lainnya dan Amerika Latin yang sangat menitik beratkan aspek material. Sebab dalam sistem bapakisme ini pada prinsipnya "bapak" atau "patron" menanggung pemenuhan kebutuhan sosial, material, spiritual, dan pelepasan pemenuhan kebutuhan emosional untuk para “anak buah"atau client. Faktor utama yang menentukan dalam "bapakisme" adalah hutang budi yang menimbulkan sikap hormat yang begitu tinggi dari "anak buah" kepada "bapak". Dalam hubungan seperti ini maka "anak buah" tidak akan pernah mau menentang "bapak"sekalipun jelas diketahui bahwa "bapak" tidak benar.

Hal ini dikarenakan tokoh-tokoh itu merupakan simbolisasi dari ideologi yang mereka perjuangkan. Di PKB, Gus Dur yang nota bene sebagai cucu dari pendiri NU, K.H. Hasyim Asyari, selalu mendapat dukungan dari warga Nadhliyin karena budaya NU yang paternalistis yang patuh pada guru, kyai atau menghormati keluarga dari gurunya. Sikap yang tidak mau berbeda dengan lingkungan sangat kental dalam lingkungan masyarakat Santri Tradisional maupun abangan, khususnya masyarakat yang tinggal di pendesaan. Pilihan politik santri tradisional ke PKB yang cukup, tidak lain karena mereka takut dianggap bukan bagian dari kelompok mereka.

\section{Kesimpulan}

Kehidupan kalangan Santri Tradisional di Malang Raya sangat disiplin menjalankan berbagai aktivitas yang berhubungan dengan ritual keagamaan. Kegiatan keagamaan tersebut melekat dengan kehidupan sosial masyarakat secara keseluruhan 
yang berimpitan dengan nilai budaya lokal, khususnya budaya Jawa. Bagi Santri Tradisional, apa yang mereka lakukan disadarinya sebagai bagian dari implementasi keberagamaan mereka termasuk dalam berpolitik atau memilih partai. Mereka lebih paham sesuatu yang tersurat dari pada yang tersirat, lebih senang dengan hal yang kongkrit/permukaan daripada substansi. Santri Tradisional yang dimaksud adalah kelompok Islam Santri dari kalangan Nahdilyin. Di Malang Raya, kelompok Santri Tradisional ini merupakan kelompok Islam mayoritas. Selama penelitian ini dilaksanakan penulis banyak melibatkan diri dalam aktivitas kelompok Santri Tradisional secara langsung, khususnya di kampung Jengglong, Dusun Caru, Desa Pendem, Kecamatan Junrejo Kota Batu. Daerah ini merupakan basis dari PKB dan PDIP, dengan mayoritas penduduknya beragama Islam (Tradisional).

Hal ini dimaksudkan untuk memahami bagaimana perilaku politik dalam kaitannya dengan kehidupan sosio-religi yang dijalankan sehari-hari. Dari hasil pengamatan penulis, warga nahdhilyin mensejajarkan $\mathrm{NU}$ dan $\mathrm{PKB}$, sehingga mereka akan merasa hilang ke NU-annya apabila tidak mencoblos PKB. Dengan demikian bagi kalangan Santri Tradisionalis, lambang, simbol menjadi hal yang sangat penting dalam kehidupan Santri Tradisional. Seorang Santri Tradisional akan sangat mudah dibedakan dengan mereka yang bukan Santri. Cara berpakaian Santri Tradisional sangat khas, dimana sarung, baju koko, peci, sorban menjadi ciri khas dari Santri Tradisional. Namun hal yang paling umum, mereka yang tergolong Santri Tradisional, adalah pemakaian sarung dalam kehidupan keseharian mereka.

Pada jaman Orde Baru, orang memilih PPP karena dianggap partai Islam yang disimbolisasikan dengan gambar ka'bah. Oleh karena itu banyak pemilih Tradisional memilih PPP walaupun banyak tekanan dari aparat maupun pemerintah. Banyak dari masyarakat yang rela dan setia untuk mendukung PPP karena mereka menganggap dengan memilih PPP berarti sudah bisa menjalankan dan membela Islam. Apalagi dalam gambar PPP ada ka'bah nya yang merupakan simbolisasi dari Islam. Melihat kenyataan ini pemerintah Orba merasa perlu untuk melakukan rekayasa, sehingga pemerintah meminta lambang ka'bah diganti. Ketika jaman Orde Baru banyak pemilih Santri 
Tradisional memilih PPP dengan alasan bahwa partai ini merupakan satu-satunya partai Islam. Apalagi ketika PPP di pimpin oleh Idham Cholid yang nota bene sebagai pemimpin ormas Islam Tradisional Nahdlatul Ulama (NU). Banyak para kader NU yang berjuang habis-habisan untuk mengkampanyekan dan memenangkan PPP dalam setiap pemilu yang dilaksanakan. Dorongan kuat dari pemilih Tradisional untuk membela PPP didasarkan pada keyakinan bahwa membela PPP sama dengan membela Islam, karena PPP merupakan partai Islam yang disimbolisasikan dari pemimpin teras partai yang merupakan tokoh-tokoh Islam khususnya NU. Dalam memperjuangkan PPP mereka tanpa pamrih, setiap kegiatan yang mereka lakukan untuk mengkampanyekan PPP tanpa bantuan apapun mereka jalan, bahkan untuk mendukung dan memenangkan PPP banyak pendukungnya yang rela urunan sendiri, bahkan mereka berani mati untuk membela PPP. Terkait keterlibatn NU dalam PPP (Van Bruinessen, 1994)

Pada pemilu 1999 dan 2004, walaupun PPP masih ada, namun para pemilih di Malang Raya yang berbasis Islam Tradisional mengalihkan pilihan politiknya ke PKB. Alasan yang muncul kenapa mereka tidak memilih PPP dikarenakan pimpinan PKB merupakan tokoh dan sekaligus pimpinan teras NU yang mempunyai garis keturunan langsung dari K.H. Hasyim Ashari yaitu Abdurahman Wahid atau yang di kenal dengan Gus Dur. Padahal PKB yang dideklarasikan oleh Gus Dur ini bukan merupakan partai Islam, karena dalam AD ART nya tidak mencantum Islam sebagai asas tapi Pancasila. Namun bagi pemilih Santri Tradisional itu tidak penting, karena yang mereka lihat bukan substansi dari partai itu melainkan siapa yang duduk dalam kepengurusan partai itu. Dengan demikian dapat dikatakan bahwa dikalangan pemilih Santri Tradisional, tolak ukur untuk menentukan pilihan politik partai tidak pada platform partai melainkan pada siapa tokoh yang duduk di partai itu. Hal ini merupakan bagian dari tradisi di kalangan NU yang menjadikan pemimpin agama (dalam hal ini ulama/kyai) sebagai panutan, tidak hanya untuk urusan keagamaan dan kehidupan sosial, namun juga untuk urusan politik ulama menjadi referensi dalam menentukan pilihan politik mereka.

Dari apa yang dikemukakan di atas terlihat jelas bahwa tingkat fanatisme mereka pada partai sangat tinggi. Karena dalam pandangan mereka memilih partai adalah 
juga pengejawantahan Keislaman, maka hal ini berpengaruh pada kondisi spikologis mereka yang tidak bisa menerima partai lain dengan tingkat kecurigaan yang tinggi pada pemilih lain. Kondisi ini menyimpan potensi konflik yang tinggi dengan pemilih lain ketika terjadi benturan antara sesama masyarakat yang berbeda, terutama ketika saat kampanye terbuka. Bahkan banyak dari pemilih Tradisional menganggap bahwa mereka yang tidak memilih partai yang sama dengan mereka tidak baik keislamannya, sehingga cenderung dijauhi oleh kelompoknya.

Di sisi lain, banyak pemilih Santri Tradisional enggan meninggalkan partai pilihannya karena alasan merasa tidak tenang. Mereka merasa apabila tidak memilih partai yang sesuai dengan kelompoknya, keislaman dia menjadi berkurang. Oleh karena itu mereka akan sangat bangga apabila memiliki kaos yang berlambangkan partai, khususnya partai PKB yang logonya mirip dengan logo Nahdatul Ulama dengan bintang sembilannya. Implikasi dari kebanggaan akan keislaman mereka yang ditranslasikan dalam pimilihan partai. Para pemilih dan pendukung PKB di Malang Raya sebagai mana saya teliti, ada sikap-sikap heroik yang muncul dari para pendukung PKB. Bahkan anggapan mereka membela PKB disamakan dengan membela agama. Dengan demikian mereka akan rela datang ke tempat-tempat kampanye yang diadakan PKB sejauh apapun dan dengan biaya sendiri.

Perbedaan yang cukup menonjol antara kelompok Santri Modernis dan Santri Tradisional adalah tradisi dalam melakukan sosialisasi dan transfer keilmuan. Di kalangan Santri Modern, sosialisasi dan transfer keilmuan lebih banyak dilakukan lewat buku-buku teks, sehingga dikenal dengan budaya baca. Bagi kelompok Santri Tradisional, transfer keilmuan lebih banyak dilakukan lewat kyai, sehingga lebih dikenal dengan budaya lisan. Perbedaan dalam proses sosialisasi dan transfer keilmuan di antara kedua kelompok ini telah berbengaruh pada kultur serta perilaku keberagamaan masing-masing. Transfer keilmuan lewat buku dalam kelompok Santri Modernis telah melahirkan sikap dan perilaku independen yang tidak taklid pada seseorang. Di sisi lain, budaya lisan yang telah dikembangkan dalam tradisi pesantren, telah membangun hubungan kuat antara kyai dan santri termasuk masyarakat yang memposisikan kyai sebagai patron. Dengan 
demikian posisi kyai menjadi dominan dan sentral dalam kehidupan kelompok Santri Tradisional, sebaliknya santri dan masyarakat berada pada posisi dependen.

Lebih jauh, perbedaan antara kelompok Santri Modernis dan Tradisional juga pada agen sosialisasi. Di Malang Raya, keluarga, sekolah formal, organisasi menjadi agen yang paling menonjol dalam proses sosialisasi nilai-nilai dan doktrin di kalangan kelompok Modernis. Bagi kelompok Tradisional, pesantren, Langgar atau Mesjid, acara pengajian, Yasinan, Tahlilan lebih berperan dalam proses sosialisasi berbagai doktrin serta adat dan kebiasaan yang melingkupi kehidupan kelompok masyarakat Islam Tradisional. Berbagai acara lain yang mempunyai keterkaitan dengan kehidupan beragama Santri Tradisionalis, seperti ziarah ke makam para wali, ataupun kunjungan tetap tiap bulan kepada kyai-nya menjadi bagian yang tidak terpisahkan dalam kehidupan Santri Tradisionalis. Hal itu semua menjadi proses pembentukan identifikasi bagi kalangan masyarakat yang mengatasnamakan dirinya sebagai kelompok Santri yang tergabung dalam Nahdlatul Ulama (NU).

Terbentuknya identifikasi melalui melalui sosialisasi tata nilai dan norma yang berkembang dalam satu kelompok masyarakat berfungsi sebagai filter terhadap norma-norma lain yang dianggap berbeda atau bertentangan. Dalam hal ini kelompok Nahdilyin yang mempunyai norma-norma berbeda akan menolak pengaruh yang datang dari kelompok masyarakat Muhammadiyah. Makanya tidaklah mengherankan apabila warga Nahdilyin di tingkat grassroot menganggap Muhammadiyah sebagai "agama baru", atau "Islam murni" yang secara praktik keagamaan banyak yang tidak bisa diterima oleh warga NU di tingkat grassroot. Warga NU sering melakukan tahlilan, kajatan dan berbagai ritual lain yang umumnya melibatkan tokoh agama lokal yaitu Kyai. Sementara orang Muhammadiyah tidak mengenal tahlilan, Yasinan, dan berbagai kajatan lainnya, padahal dalam kontek masyarakat NU kegitan-kegitan itu tidak melulu urusan keagamaan tetapi juga sudah menjadi bagian dari kehidupan sosial, dimana kyai sebagai pemimpinnya. Dan umumnya para kyai yang menjadi tokoh agama di tingkat grassroot adalah mereka yang mempunyai kedekatan dengan tokoh-tokoh PKB atau sekaligus mereka juga menjadi pengurus PKB pimpinan Gusdur. Oleh karena itu ketika PAN 
diasosiasikan dengan Muhammadiyah maka PAN sulit untuk mendapat simpati dari anggota masyarakat Nahdliyin.

\section{Daftar Rujukan}

\section{Buku}

Alfian. (1989). Mubammadiyah: The Political Behavior of a Muslim Modernist Organisation Under Dutch Colonialism. Yogyakarta: Gadjah Mada University Press.

Arifin, Imron. (1993). Kepemimpinan Kyai: Kasus Pondok Pesantren Tebuireng. Malang: Kalimasahada Press.

As'ad, M.Z. Widjaja. (1991). Elit Agama dan Massa Pemilih dalam Perspektif Budaya Politik. Unpublished MA thesis. Yogyakarta: Gadjahmada University.

Asher, Herbert B. (1988). Presidential Elections and American Politics, 4th ed., Homewood, Ill,: Dorsey Press.

Azra, Azyumardi. (2002). Reposisi Hubungan Agama dan Negara, Jakarta: Penerbit Buku Kompas. , dkk. (2004). Pergulatan Partai Politik Di Indonesia, Jakarta: PT. RajaGrafindo.

Barton, Greg and Fealy, Greg ed. (1996, forthcoming). Nabdlatul Ulama, Traditional Islam and Modernity in Indonesia. Centre of Southeast Asian Studies, Monash University.

Berelson, Bernard R., et.al,. (1954). Voting, University of Chicago Press, Chicago.

Bernard, Lewis. (2002). Islam Liberalisme Demokrasi, Terj. Mu’im A Sirry, Cit. I. Jakarta: Para Madina.

Binder, Leonard. (1959). "Islamic Tradition and Politics: The Kyai and the Alim", Comparative Study in Society and History, (2): 250-256.

, et al. (1971) Crises and Sequences in Political Development, New Jersey: Princeton University Press.

Bibby, John F. (1992). Politics, Parties, and Elections in America, Chicago: Nelson-Hall Publishers.

Boboy, Max, SH. (1994). DPR RI Dalam Perspektif Sejarah dan Tata Negara, Jakarta: Pustaka Sinar Harapan. 
Bogdan, Robert dan Steven J. Taylor. (1992). Pengantar metoda penelitian kualitatif: Suatu Pendekatan Fenomenologis Terhadap Ilmu-ilmu Sosial, (Diterj. Arief Furchan) Surabaya: Usaha Nasional.

Bone and Ranny. (1980). Politics and Voters, Mc. Graw-Hill inc.Illiones.

Bourchier and Legge John (editor). (1994) Democracy In Indonesia 1950 and 1990s. Australia: Aristoc press Pty.

Bogdan, R.C. And Taylor. (1992). Introduction to Qualitative Research Methods: A Phenomenological Approach to The Social Sciencies. New York: John Wiley \& Sons.

Brannen, Julia. (1993). Mixing Methods: Qualitative and Quantitative Research. USA:Ashgate Publishing Company.

Bruinessen, Martin van. (1994). NU: Tradisi, Relasi-Relasi Kuasa, Pencarian Wacana baru, Yogyakarta : LKIS. (1992). Tarekat Naqsyabandiyah di Indonesia. Bandung : Mizan. (1995). Kitab Kuning, Pesantren dan tarekat: Tradisi-Tradisi Islam di Indonesia, Bandung : Mizan.

Fathoni, Khoerul and Muhammad Zen. (1992). NU Pasca Khittah: Prospek Ukhumwah dengan Muhammadiyah. Yogyakarta: Media Widya Mandala.

Fealy, Greg .(2003). Ijtihad Politik Ulama, Sejarah NU 1952-1967, Yogyakarta: LP3ES.

Feith, H. (1970). "Introduction". In Feith and Castle, Lance ed. Indonesian Political Thinking, 1945-1965. Ithaca : Cornell University Press. (1978). The Decline of Constitutional Democracy in Indonesia, Ithaca and London: Cornell University Press. , (1957). Indonesian Elections of 1955, Modern Indonesia Project Southeast Asia Program, Ithaca, New York: Cornell University.

Fisher, Michael M.J. (1980). Iran: From Religious Dispute to Revolution. Cambridge : Harvard University Press.

Fox, James J. (1991). "Ziarah Visits to the Tombs of the Wali, the Founders of Islam on Java". In Ricklefs, M.C. Islam in the Indonesian Context. Clayton, Victoria : 
Centre for Southeast Asian Studies, Monash University.

Gaffar, Afan. (1992). Javanese Voters, A Case Study of Election Under Party a Hegemonic Party System. Yogyakarta: Gadjah Mada University Press.

Geertz, Clifford. (1960). The Religion of Java. Glencoe : The Free Press.

, Clifford. (1959) "The Javanese Kyai: The Changing Role of a Cultural Broker", Comparative Studies in Society and History, (2): 250-256.

, Clifford. (1965) The Social History of an Indonesian Town. Cambridge, Massachusets : MIT Press.

, Clifford. (1981). Abangan, Santri, Priyayi Dalam Masyarakat Jawa, Jakarta: Pustaka Jaya , (1965). Children and Politics, New Haven. Conn: Yale University Press.

Haidar, M Ali. (1994). Nabdatul Ulama dan Islam di Indonesia: Pendekatan Fikib dalam Politik. Jakarta : Gramedia Pustaka Utama.

Hagopian, N., Mark. (1978). Regime, Movements and Ideologies. New York and London: The University of Chicago Press.

Hammond, J.L. (1979). The Politics of Benevolence: Revival Religion and American Voting Behaviour. Norwood: Ablex Publishing Corporation.

Haryanto. (1984). Partai Politik Suatu Tinjauan Umum. Yogyakarta: Liberty.

Harrop, Martin (dkk). (1992). Political Science, A comparative Introduction. Great Britain: The Macmillan Press LTD. , Martin (dkk). (1987). Election and Voters. London: The McMillan Press.

Karim, M. Rusli (1992) Islam dan Konflik Politik Era Orde Baru, Yogyakarta: Media Widya Mandala.

Kartodirdjo, Sartono, (1973) Protest Movement in Rural Java: A Study of Agrarian Unrest in the Nineteenth and Early Twentieth Century, Kuala Lumpur : Oxford University Press.

Kazhim, M. dan Alfian Hamzah, (1999) Lima Partai Dalam Timbangan, Bandung: Pustaka Hidayah. 
Lazarsfeld, Paul, Berbard Berelso, and Hazel Gaudet, (1944) The People Choice. New York: Columbia University Press. , (1962). Political Ideology. New York: The Free Press. , (1969). Political Thinking and Consciousness. Chicago: Markham Publishing.

Lev, S. D. (1966). The Transition to Guide Democracy: Indonesian Politcs, 1957-1959, Monograph Series, Modern Indonesian Project, New York: Cornell University.

Liddle, W.R. (1978). Participation and the Political Parties. In Jackson, Karl D and Pye, Lucian ed. Political Power and Communication in Indonesia. Berkeley : University of California Press. , (1978). The 1977 Indonesia Election anf New Orde Legitimasy, Southeast Asian Affair (Singapura: Institute for Southeast Asia Affair Asia Studies, 1978.a) , (1974). "Power, Participation and The Political Party in Indonesia", Center for International Studies, MIT, , (1992). “Sungai Budaya. Tempo. 12 April.

Mair, Peter., et.al. (2004). Political Party and Electoral Change, London: SAGE Publications Ltd.

, Cleavages, dalam Ricard S Katz and William Crotty , (edt), 2006, Hand Books of Party Politics, Calipornia: SAGE Publication.

Majid, Nurcholis. (1996). Ketegangan Kultur Pesisir dan Kultur Pedalaman (Menelusuri Kultur Politik Orde Baru), Jakarta: Yayasan Lintas Informasi.

Mintadireja, S., M. (1971). Masyarakat Islam dan Politik Indonesia. Djakarta: Permata Djakarta.

Mujani, Saeful. (2007). Muslim Demokrat, Islam, Budaya Demokrasi, Dan Partisipasi Politik Indonesia Pasca Demokrasi. Jakarta: PT Gramdia Pustaka Utama.

Mulkan, M. A. (1988). Perubahan Perilaku Politik dan Polarisasi Ummat Islam, Dalam Prespektif Sosiologis. Jakarta: CV. Rajawali.

Noer, Deliar (1980) Gerakan Moderen Islam di Indonesia, 1900-1942, Jakarta: LP3ES. , (2006). Partai Islam di Pentas Nasional, Cet. I, Bandung: Mizan. 
Nurjaman, Asep. (1998). Kepolitikan Orde Baru Dalam Prespektif Struktural Dan Kultural. Malang: UMM Press.

Pomper, Gerald. (1966). Politics: Essay and Reading, USA: Rinehart and Winston, Inc. , (1975). Voter's Choice: Varieties of American Electoral Behavior. New York: Dodd, Med Company.

Samson, Allan A. (1978). Conception of Politics, Power, and Ideology in Contemporary Indonesian Islam. In Jackson, Karl D and Pye, Lucian ed. Political Power and Communication in Indonesia. Berkeley: University of California Press.

Sartori, Geovanni. (1959). Parties and Party System, A Framework for Analysis. New York: Cambridge University Press.

Schwarz, Adam. (1994). Nation in Waiting, Austalia: Allen \& Unwin Pty Ltd.

Sherman, Arnold, K. dan Aliza Kolker. (1987). The Social Bases of Politics. California: Division of Worswath.

Siregar, A. (penyunting). (1985). Pemikiran Politik dan Perubaban Sosial, Seri Pemikiran Politik 1. Jakarta: CV. Akademi Pressindo.

Smith, D.E. (1971). Religion, Politics, and Social Change in the Third World. New York: Free Press.

Sulistyo, Hermawan. (2000). Palu Arit Di Ladang Tebu: Sejarah Pembantaian Massal yang Terlupakan (1965-1966). Jakarta: Kepustakaan Populer Gramedia.

Sundhaussen. (1978). "The Military: Structure, Procedures and Effects on Indonesian Society". In Jackson, Karl D. and Pye, Lucian ed., Political Power and Communication in Indonesia. Berkeley : University of California Press.

Surbakti, Ramlan. (1992). Memahami Ilmu Politik. Indonesia: Gramedia Widya Sarana.

Syamsuddin, D. (editor). (1990). Muhammadiyah Kini dan Esok. Jakarta: Pustaka Panjimas.

Thohari, Hajriyanto Y. (2002). Kepemimpinan Nasinal, Antara Primodialisme dan Akuntabilitas, dalam Maruto MD dan Anwari WMK, (editor), Reformasi Politik dan Kekuatan Masyarakat, Kendala dan Peluang Menuju Demokrasi, Pustaka LP3ES Indonesia, Jakarta. 
Waltzer, Herbert (dkk) .(1971). Ideologies And Modern Politics, Toronto USA: Dodd, Mead \& Company.

\section{Publikasi Ilmiah}

Ali, Fachry. (1994). How State Comes to the People?: the Acehnese and the New Order State. A Paper presented at the Indonesian Study group, Research School of Pacific and Asian Studies, ANU, Canberra, 8 June 1994.

, (1994). Keharusan Demokratisasi dalam Islam di Indonesia. A paper presented at a seminar held in LIPI by Majelis Sinergi Kalam, ICMI, Jakarta. (1996). Pengaruh Aliran Dalam politik Indonesia, unpublished paper.

Barness, Douglas F. (1978). "Charisma and Religious Leadership: An Historical Analysis", Journal of the Scientific Study of Religion, 17(1): 1-18.

Hefner, Robert W. (1987). Islamizing Java?: Religion and Politics in Rural East Java, The Journal of Asian Studies. 46(3): 533-553.

Mancini, Paolo. (1999). New Frontiers in Political Professionalism, Political Communication, 16.

Mochtar, Hilmy. (1989). Dinamika Nabdlatul Ulama: Suatu Study tentang Elite Kekuatan Politik Islam di Jombang Jawa Timur. Unpublished MA thesis, Gadjahmada University, Yogyakarta.

Suhardjo, Achmad. (1991). Kemerosotan Perolehan Suara PPP Pada Pemilu 1987, Studi Kasus di Kabupaten Jombang. Unpublished MA Thesis, Gadjahmada University, Yogyakarta.

Sukamto, (1992) Kepemimpinan Kiai dan Kelembagaan Pondok Pesantren. Unpublished MA Thesis, Gadjahmada University, Yogyakarta

Strom, Kaare and Stephen M. Swindel. (2002). Strategic Parliamentary Dissolution, American Political Science Review 96. 
Jurnal Sospol, Vol 3 No 2 (Juli-Desember 2017), Hlm 43-65 